\title{
Impact of Resource Conserving Technologies (RCT) on soil physical properties and rapeseed (Brassica napus L.) yield in irrigated agriculture areas of the South-Eastern Kazakhstan
}

\author{
Naziya Suleimenova *, Baglan Makhamedova, Gulnar Orynbasarova, \\ Dastan Kalykov, Zhainagul Yertayeva
}

Kazakh National Agrarian University, Almaty, Kazakhstan

\begin{abstract}
The aim of this resarch was to determine the effects of Resource Conserving Technologies (RCT) system and Conventional Tillage (CT) on soil physical properties and Rapeseed (Brassica napus L.) yield in irrigated agriculture areas of the South-Eastern Kazakhstan. The experimental study was conducted according to a radomized block design with three replications between 2015 and 2018. The CT system had maximum anthropogenic effect and caused loosening of arable soil layer, had the lowest bulk density values (1.19 -1.21 $\mathrm{g} / \mathrm{cm}^{3}$ ). The CT had a bulk density ranged between 1.13 and $1.30 \mathrm{~g} / \mathrm{cm}^{3}$. With a RCT tillage, the bulk density during the growing season of rape was located in optimal density zone between 1.20 and $1.22 \mathrm{~g} / \mathrm{cm}^{3}$. The RCT of rapeseed provided the greatest efficiency, where the yield of rapeseed increased by $13.3 \%$ and $22.0 \%$. It has been revealed that with RCT of rapeseed cultivation, minimum technology (Mini-till) ensures sustainability of soil environment and its ecological condition, improves structure and raises water resistance of agroecosystem's soil aggregate. In turn the structure of soil's arable layer stabilizes with optimal soil density, which contributes to normal growth and development of rapeseed. It is proved that minimal technology of tillage is the leading agricultural practice ensuring preservation and improvement of qualitative and quantitative indicators of soil resource and productivity of oilseed rape.
\end{abstract}

Keywords: Conservation tillage, agrophysical factors, fertility, yield.

(c) 2019 Federation of Eurasian Soil Science Societies. All rights reserved

\section{Introduction}

At the beginning of the third millennium, humanity was faced with ecosystem's limited ecological capabilities (Carpenter et al., 2006). Particularly, this case refers to the arable lands which have been used intensively under field traffic leading to decrease not only fertility and crop yield in soil but also to reduce usage of sustainable land and soil resources (Gomiero, 2016). In addition to that, in connection with the tillage systems also have the potential not only to accelerate ecological deterioration such as soil fertility loss and soil erosion but also, to reduce economical income such as increasing financial, energy and labor costs by reducing the long-term sustainability of dryland agriculture (Telles et al., 2011). A certain sequence of multiple methods of tillage takes place under traditional technology of agricultural crops' cultivation. Between 30 and $40 \%$ of the total cost for crop growth is tillage application (Townsend et al., 2016). In general for those main reasons, concept of conservation agriculture was developed. Conservation agriculture is a part of sustainable agriculture, aiming at optimizing yields and prots but also at protecting land resources and the environment. Therefore, it is necessary to focus on effective and environmentally friendly methods in terms of resource conserving technologies for field cultivation activities (Hobbs et al., 2008).

\footnotetext{
${ }^{*}$ Corresponding author.

Kazakh National Agrarian University, Almaty, Kazakhstan

Tel.: + 77015055220

e-ISSN: 2147-4249
} 
In recent years, systemic measures have been taken in agriculture field in the Republic of Kazakhstan to apply highly efficient Resource Conserving Technologies (RCT). Separate elements of this (No-tillage) technology were introduced in northern Kazakhstan as a system for soil protection which contributed to slow down soil erosion processes and increased the yield of grain crops (FAO, 2013: Saparov, 2014). Moreover, in different agricultural zones of the Republic of Kazakhstan, the basic principles of resource conserving agriculture has been developed by applying mulch system with plant residues and reduction or completely non mechanical tillage. Thus, zero tillage technology is contributing to enhanced sustainability of dryland agriculture in the region by reducing erosion, and improving soil quality and soil ecosystem services (Franzluebbers, 2002; Bessam and Mrabet, 2003; Kassam et al., 2009; Palm et al., 2013; Acar et al., 2018).

Conservation agriculture involves zero or minimum soil disturbance through tillage (no-tillage, reduced tillage, mulch tillage and strip-tillage), a balanced use of fertilizers and herbicides, a permanent soil biomass cover enhancing water and soil conservation, crop rotation and integrated pest management, reduced production costs and increased farming efficiency (Mrabet et al., 2001; Kassam et al., 2009; Ruiz-Colmenero et al. 2013; Chauhan et al., 2012). As for minimal technology (Mini-till), the number of soil's mechanical treatments is also reduced, continuous action herbicides replace the systems of mechanical pre-sowing and intermediate tillage and instead of deep processing, and small flat-cutting treatment is used. The use of environmentally correct techniques of technology that fit into biochemical circulation of agroecosystem resources ensures creation of sustainable competitive agrophytocenosis (Duru et al., 2015). Therefore, the objective of this manuscript was to investigate the effects of resource conserving technology techniques on soil physical properties and rapeseed (Brassica napus L.) yield in irrigated agriculture areas of the SouthEastern Kazakhstan.

\section{Material and Methods}

\section{Study site description}

Experimenal studies were carried out at the Turgen private farm "Agrouniversity" training and experimental farm of KazNAU found on the foot slope position of the Northern part of the Ili Alatau in the irrigated agriculture zone used under intensive acricultural activity and located at in South-Eastren part of the Kazakhistan (Figure 1). The study area is situated between 550 and $700 \mathrm{~m}$ elevation from sea level.

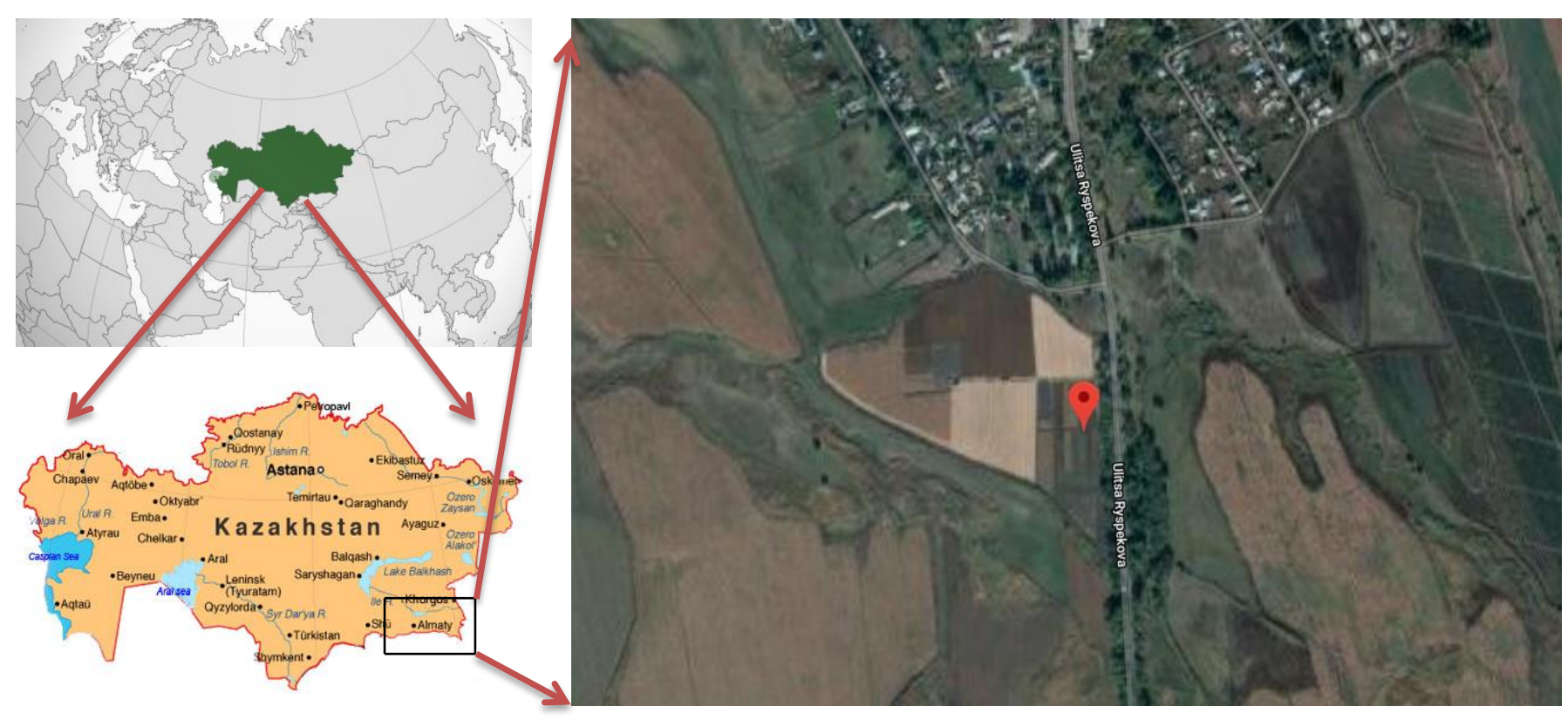

Figure 1. Location map of the study area

The climate type of study area is "Continental Climate" which can be described as low humidity, plenty of sunlight, a short but rather cold winter. The average annual air temperature is $7.7^{\circ} \mathrm{C}$. The average long-term sum of precipitation for a period with temperature above $10^{\circ} \mathrm{C}$ is $240-350 \mathrm{~mm}$ with a total evaporation volume of moisture during this period $(1550-1720 \mathrm{~mm})$. The duration of the frost-free period is $158-175$ days. Monthly average precipitation and temperature values of the study area is given Figure 2 . 

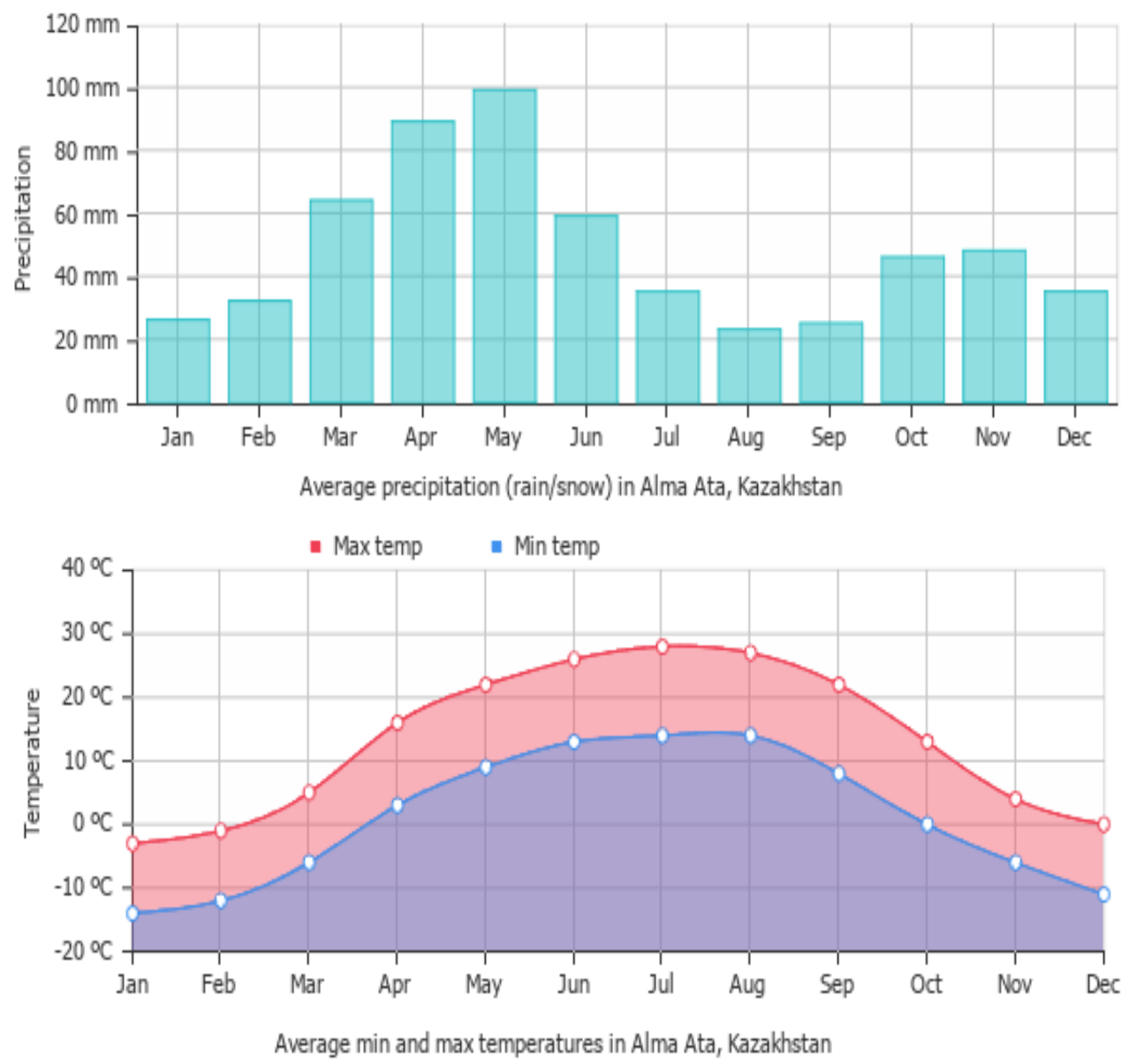

Figure 2. Monthly average precipitation and temperature values of the study area

\section{Soil properties in study site}

Before the beginning of the experiment, some properties of the soil were determined. After taking soil samples from surface depth $(0-20 \mathrm{~cm})$, some phsico-chemical analyses were conducted on air-dried samples stored at room temperature and from which crop residues, root fragments and rock larger than $2 \mathrm{~mm}$ in diameter had been removed. Selected some soil chemical properties were determined by the methods of Rowell (1994) and Jones, Jr. (2001). Research area soil is slightly alkaline with $7.3 \mathrm{pH}$ value in 1:1 (w/v), while amount of their average $\mathrm{CaCO}_{3}$ is about $5.8 \%$. In addition, organic matter content, $\mathrm{C} / \mathrm{N}$ ratio and total mineral nitrogen $\left(\mathrm{NH}_{4}+\mathrm{NO}_{3}\right)$, available phosphorus and available potassium of the surface soil are $4.45 \%$, $11.8,87 \mathrm{mg} / \mathrm{kg}, 435.1 \mathrm{mg} / \mathrm{kg}$ and $22 \mathrm{mg} / \mathrm{kg}$, respectively. These ratios decreased with increasing soil depth. According to the soil classification system, soil of experimanetal area was calssifed as meadow chesnut. In addition, some soil chemical characteristic values of meadow chesnut are given in Table 1. Moreover, physical properties of meadow chestnut soil is potentially fertil and satisfies the conditions to cultivate all types of crops particularly for oilseed rape.

Table 1. Some properties of meadow chestnut soil

\begin{tabular}{ccccccc}
\hline \multirow{2}{*}{ Depth, cm } & $\begin{array}{c}\text { Organic } \\
\text { matter, } \%\end{array}$ & $\begin{array}{c}\text { Total } \\
\text { nitrogen, } \%\end{array}$ & C:N & $\begin{array}{c}\text { Total potassium, } \\
\%\end{array}$ & $\begin{array}{c}\text { Total phosphorus, } \\
\%\end{array}$ & $\begin{array}{c}\mathrm{CaCO}_{3}, \\
\%\end{array}$ \\
\hline $0-24$ & 4,45 & 0,120 & 21,51 & 2,60 & 0,19 & 5,80 \\
$24-32$ & 4,40 & 0,119 & 21.44 & 2,10 & 0,16 & 5,84 \\
$32-59$ & 1,00 & 0,060 & 9,66 & 1,09 & 0,17 & 5,88 \\
$59-103$ & 0,46 & 0,039 & 6,84 & 1,10 & 0,14 & 7,30 \\
\hline
\end{tabular}

\section{Experimental design and tillage systems}

In order to determine effect of different soil tillage systems on some soil physical properties such as soil aggregate stability, bulk density, and yield of Rapseed (Brassica napus L.), the experimental studies were performed between 2015 and 2018. In this study, main plot treatments were the two soil tillage methods, Conventional Tillage (CT) and Resource Conserving Technology (RCT), sub-plot treatments were three primary soil tillage methods (Tillage at $20-22 \mathrm{~cm}$, Flat-cut tillage at $16-18 \mathrm{~cm}$ and Flat-cut tillage at $12-14$ 
$\mathrm{cm}$ ), and sub-sub-plot treatments were three Pre-sowing soil tillage methods (Cultivation at 10-12 $\mathrm{cm}$ by harrowing, Loosening at $12-14 \mathrm{~cm}$ and Disking at 8-10 cm). Each sub-sub plot was sized as $20 \mathrm{~m} \times 5 \mathrm{~m}(100$ $\mathrm{m}^{2}$ ) and total plot number was 27. Each treatment was performed in three replicate plots. The plant densities of $15 \times 10^{4}-45 \times 10^{4}$ plant ha-1 and row spacings from $15-35 \mathrm{~cm}$ used in the study are widely used for Rapeseed production in the Almaty region. Different tillage methods used in the study were given in Table 2.

Table 2. Different tillage applications

\begin{tabular}{|c|c|c|}
\hline $\begin{array}{l}\text { Soil Tillage } \\
\text { Methodology- A }\end{array}$ & Primary soil tillage-B & $\begin{array}{c}\text { Soil Tillage system } \\
\text { Pre-sowing soil tillage - C }\end{array}$ \\
\hline $\begin{array}{l}\text { A } 1 \\
\text { Conventional Tillage } \\
\text { (CT) }\end{array}$ & $\begin{array}{l}\mathbf{B}_{1} \\
\text { Tillage at } 20-22 \mathrm{~cm}\end{array}$ & $\begin{array}{l}\mathbf{C}_{1}-\text { Cultivation at } 10-12 \mathrm{~cm} \text { by harrowing } \\
\mathbf{C}_{2}-\text { Loosening at } 12-14 \mathrm{~cm} \\
\mathbf{C}_{3}-\text { Disking at } 8-10 \mathrm{~cm}\end{array}$ \\
\hline \multirow{2}{*}{$\begin{array}{l}\mathbf{A}_{2} \\
\text { Resource Conserving } \\
\text { Technology (RCT) }\end{array}$} & $\begin{array}{l}\mathbf{B}_{2} \\
\text { Flat-cut tillage at } 16-18 \mathrm{~cm}\end{array}$ & $\begin{array}{l}\mathbf{C}_{1}-\text { Cultivation at } 10-12 \mathrm{~cm} \text { by harrowing } \\
\mathbf{C}_{2}-\text { Loosening at } 12-14 \mathrm{~cm} \\
\mathbf{C}_{3}-\text { Disking at } 8-10 \mathrm{~cm}\end{array}$ \\
\hline & $\begin{array}{l}\mathbf{B}_{3} \\
\text { Flat-cut tillage at } 12-14 \mathrm{~cm}\end{array}$ & $\begin{array}{l}\mathbf{C}_{1}-\text { Cultivation at } 10-12 \mathrm{~cm} \text { by harrowing } \\
\mathbf{C}_{2} \text { - Loosening at } 12-14 \mathrm{~cm} \\
\mathbf{C}_{3}-\text { Disking at } 8-10 \mathrm{~cm}\end{array}$ \\
\hline
\end{tabular}

In all plot, Rapseed (Brassica napus L.) seeds were placed at 2-2.5 cm depth in dry soil. Sowing of rapeseed carried out with a seeding rate of 2.5 million pieces/ha. Rapeseed was manually sown on the September. The seed density was evaluated directly after seedling emergence and adjusted for precise planting density at the five-leaf growth stage for all plots. Before sowing, Phosphorus and potassium fertilizer, as an agricultural background were applied as a basal fertilizer. Pest, disease (Cruiser -the active ingredient is Thiamethoxam, and Karate -the active ingredient is Lambda-cyhlothrin) and irrigation (two to three times at a rate of 400$420 \mathrm{~m}^{3} / \mathrm{ha}$ ) were performed according to local management practices. In the fight against weeds in the sowing of rapeseed, the herbicide (Impulse) was also used in an environmentally safe dose (0.7 L/ha) in RCT plots.

\section{Harvesting and harvest measurements}

Plots were harvested when approximately $2 / 3$ of the seed was brown. Rapeseed (Brassica napus L.) yield and yield components were determined by adopting the standardized Crop Cut Method (Sapkoda et al., 2016). On each plot, the following measurements and observations were made: the plant density $\left(\mathrm{m}^{2}\right)$, pods per plant, seeds per plant and the 1000-seed-weight $(\mathrm{g})$. Then, the remaining plants in each plot were manually harvested to measure the manually harvesting seed yield (t/ha). After the fresh weight was determined, the roots and the aboveground tissues were dried in an oven for $30 \mathrm{~min}$ at $105^{\circ} \mathrm{C}$ to deactivate enzymes and then dried at $70^{\circ} \mathrm{C}$ until a constant weight was reached for dry weight determination.

\section{Soil sampling and analysis}

Bulk soil samples were taken 2015-2018 period in undisturbed state from the experiment within each parcel at at $0-20 \mathrm{~cm}$ soil depth and kept in laboratory for analyses. Soil bulk density was analized by volume weight using the Kachinsky method (Kachinsky, 1958). Porosity and degree of aeration were determined by calculation. Aggregate size distribution was determined by the standard dry-sieving method (Savinov, 1936).

\section{Economic analysis}

A simple economic analysis was done based on total production. Production cost included rental charge of the land and input cost. The input cost was calculated by considering cost of seed, fuel, fertilizers, pesticide, hiring charges of labour. Fuel consumption was measured by filling the fuel tank twice, before and after each operation, with the re-filled volume being the actual fuel consumption. The gross income and net returns were calculated on the basis of market price for Rapseed. Price of the product was based on local market to compute total production cost, gross return, gross margin and benefit-cost ratio. The net returns were calculated by subtracting total variable costs from the gross income.

\section{Statistical analysis}

Analysis of variance (ANOVA) was performed using Duncan's multiple range test. ANOVA and the LSD test were conducted using the KazNAU using data processing methods. 


\section{Results and Discussion}

In addressing the problem of developing and introducing RCT for cultivation of oilseed crops such as rape (Brassica napus L.), it was identified that resupply techniques provide and enable to reveal hidden forms of stability disorders to maintain agro-ecosystem's stability. Thus, agro-ecosystem made it possible to determine the ecological situation under traditional and resource conserving cultivation technology. As a result of controlling abiotic, biotic and anthropogenic factors, the negative influence of traditional technology of rapeseed cultivation on agroecosystem's ecological situation was revealed.

\section{Bulk density}

The tillage applications did lead significant differences on bulk density in average of 3 years of the experiment (Table 3). Generally, soil bulk density was increased in RCT, while decreased in CT. Kanwar (1989) and Meek et al. (1992) reported that tillage systems have altered bulk density and porosity of soils. Decreasing the number, intensity and depth of tillage induced to obtain higher bulk density values (Table 3). The increases in bulk density of the soil with no-tillage treatments have previously been reported by Xu and Mermoud (2001). Contrasting results have been reported for the effects of soil tillage systems on bulk density. Greater bulk density values under conventional tillage systems were reported when compared to no-tillage (Dao, 1996; Roscoe and Buurman, 2003).

When compared soil bulk density in two different tillage methods (CT and RCT), it was found that under CT, which has maximum anthropogenic effect and causes loosening of arable soil layer, has the lowest values $\left(1.19-1.21 \mathrm{~g} / \mathrm{cm}^{3}\right)$ in $16-18 \mathrm{~cm}$. This case can be explained that after preparing seed bed, the density of soil in arable layer was naturally decreased, thus, it created optimal condition for the initial period of growing season. On the other hand, in soil bulk density of $12-14 \mathrm{~cm}$ soil depth slightly increased about $1.20-1.22$ $\mathrm{g} / \mathrm{cm}^{3}$. With tillage minimization (RCT), the soil bulk density is on average $1.20 \mathrm{~g} / \mathrm{cm}^{3}$. The data obtained by volume mass indicate the close dependence of arable soil layer's composition on the system of primary tillage. The value of the bulk mass of $0-30 \mathrm{~cm}$ of soil layer, with the conventional tillage indicates a loose composition with a bulk mass within range of $1.13 \mathrm{~g} / \mathrm{cm}^{3}$ and $1.30 \mathrm{~g} / \mathrm{cm}^{3}$ (Table 3).

The influence of main and pre-sowing treatment on soil bulk density, the day of sowing rape by horizons, average over the years of research indicates that comparing to main flat-cutting of soil to a depth of 16-18 $\mathrm{cm}$, provides an increase in soil bulk density at a depth of $0-30 \mathrm{~cm}$ from 1.19 to $1.21 \mathrm{~g} / \mathrm{cm}^{3}$. Against the same background, at depth of $12-14 \mathrm{~cm}$ of tillage in all variants of pre-sowing tillage, an increase in the soil bulk density revealed up to $1.20-1.22 \mathrm{~g} / \mathrm{cm}^{3}$. With tillage minimization (RCT), the soil density varies within the limits of optimal addition, where the bulk density is an average of $1.20 \mathrm{~g} / \mathrm{cm}^{3}$. The data obtained by volume mass indicated that there was the close dependence of arable soil layer's composition with the system of primary tillage. The value of the bulk mass of $0-30 \mathrm{~cm}$ of soil layer, with the CT indicates a loose composition with a bulk density ranged between $1.13 \mathrm{~g} / \mathrm{cm}^{3}$ and $1.17 \mathrm{~g} / \mathrm{cm}^{3}$ (Table 3 ).

Table 3. Effect of Conventional Tillage (CT) and Resource Conserving Technology (RCT) on bulk density (average of 3 years)

\begin{tabular}{|c|c|c|c|c|}
\hline \multirow{2}{*}{ A } & \multirow{2}{*}{ B } & \multirow{2}{*}{ C } & \multicolumn{2}{|c|}{ Bulk density of $0-30 \mathrm{~cm}$ soil layer, $\mathrm{g} / \mathrm{cm}^{3}$} \\
\hline & & & Before sowing & Before harvesting \\
\hline \multirow{3}{*}{$\mathrm{A} 1$} & \multirow{3}{*}{ B1 } & C1 & 1.14 & 1.27 \\
\hline & & $\mathrm{C} 2$ & 1.17 & 1.28 \\
\hline & & $\mathrm{C} 3$ & 1.13 & 1.30 \\
\hline \multirow{6}{*}{ A2 } & \multirow{3}{*}{ B2 } & C1 & 1.19 & 1.30 \\
\hline & & $\mathrm{C} 2$ & 1.20 & 1.31 \\
\hline & & C3 & 1.21 & 1.32 \\
\hline & \multirow{3}{*}{ B3 } & $\mathrm{C} 1$ & 1.20 & 1.31 \\
\hline & & $\mathrm{C} 2$ & 1.20 & 1.32 \\
\hline & & $\mathrm{C} 3$ & 1.22 & 1.32 \\
\hline
\end{tabular}

A1: Conventional Tillage (CT), A2: Resource Conserving Technology (RCT)

When studying soil density by volume mass in dynamics, it was found that under CT system, the maximum anthropogenic effect of dump plowing manifests itself which causes loosening of arable soil layer. After preparing the field for sowing, the bulk density of arable soil layer naturally decreased, and it was optimal at the initial period of growing season and development of rape growth. The obtained results of soil's bulk mass before sowing rape showed that replacement of costly, energy-saturated traditional dump plowing with RCT with flat-cut treatments to a depth of $16-18 \mathrm{~cm}$ and $12-14 \mathrm{~cm}$ contributes to creating an optimal composition of soil's arable layer in initial period of rapeseed development. 
Soil bulk density of 0-30 cm soil layer by the end of rapeseed growing season in all treatments increased from $1.20 \mathrm{~g} / \mathrm{cm}^{3}$ to $1.27 \mathrm{~g} / \mathrm{cm}^{3}$. Under CT with dumping plowing, the top 0-30 $\mathrm{cm}$ layer of soil is compacted

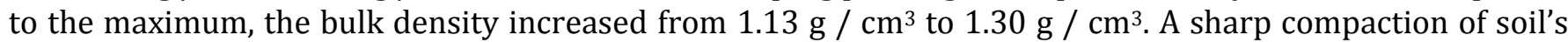
arable layer causes a disturbance of soil's water regime due to high physical evaporation of moisture and numerous gaps in root system of plants associated with a sharp compaction of the entire root-soil layer.

On the variants of minimal tillage (RCT) during the growing season of rape, soil is compacted moderately and risks for development of plant root system are not created. Before harvesting rapeseed, the bulk density increased from 1.19 to $1.30 \mathrm{~g} / \mathrm{cm}^{3}$ minimally under flat-cut processing for a depth of $16-18 \mathrm{~cm}$, and from $1.20 \mathrm{~g} / \mathrm{cm}^{3}$ to $1.30 \mathrm{~g} / \mathrm{cm}^{3}$ for a depth of $12-14 \mathrm{~cm}$ (Figure 3).

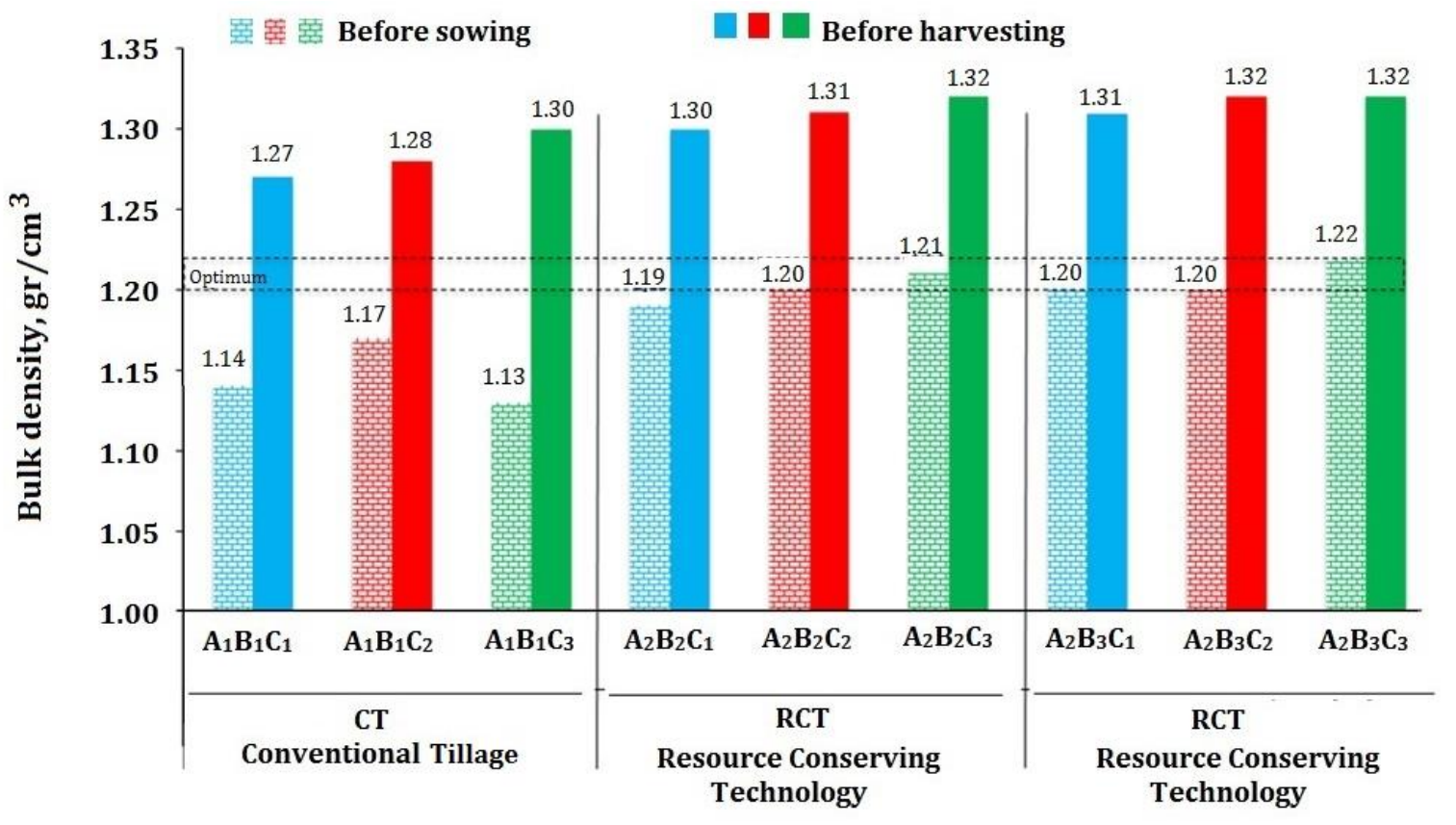

Figure 3. Effect of different tillage systems (CT and RCT) on dynamics of soil bulk density (average of 3 years)

With a RCT (implemented by flat-cut) tillage, the bulk density during the growing season of rape was located in optimal density zone between 1.20 and $1.22 \mathrm{~g} / \mathrm{cm}^{3}$. Namely, the optimal addition of arable layer of soil takes place in variants of RCT of rapeseed cultivation with Mini-till. The soil bulk density in both studied variants of flat-cut tillage to a depth of $16-18 \mathrm{~cm}$ and $12-14 \mathrm{~cm}$, as well as in case of RCT is within the optimum value (1.19-1.20 g/ $\left.\mathrm{cm}^{3}\right)$ for normal growth and development of rapeseed.

\section{Aggregate stability}

The overall results of the experiment revealed a strong influence of tillage on aggregate size distribution and mean weight diameter in the average of 3 years, at the $0-20 \mathrm{~cm}$ soil depth (Table 4). The quantity of fine aggregates $(<0.25 \mathrm{~mm})$ in RCT compared to CT. Tisdall and Oades (1982) also reported that the stability of macro-aggregates $(>0.25 \mathrm{~mm})$ was controlled by soil management (tillage, rotations, etc.), but the stability of micro-aggregates $(<0.25 \mathrm{~mm})$ depended on amount and stability of organic sementing agents and seemed to be independent of soil management.

Of the two tillage systems, better aggregate stability of the soil was observed in RCT, as seen by the high percentage of micro-aggregates of diameter $<0.25 \mathrm{~mm}$ at a depth of 0 to $10 \mathrm{~cm}$ (range from a minimum of $42.5 \%$ to a maximum of $48.3 \%)$ with respect to that calculated in CT (28.1\% to $37.0 \%)$ (Table 4$)$. The better structure in RCT could be attributed to the effect of different agents that intervene in the aggregate stability. On the one hand, this could be due to a higher organic matter content as a consequence of the incorporation to the soil of residues coming from winter cropping and on the other hand, to that during the tillage operations, by the effect of soil turning, compacted horizons would be taken to the surface, forming stable aggregates that would arise from the compression (Silva and Mielniczuk, 1998) and not from the biological action of roots or microorganisms.

Effects of CT and RCT on water stable aggregates in average of 3 years of the experiment are given in Table 4. Generally, sum of water stabile aggregates was increased in RCT, while decreased in CT. There were 
differences between sum of water stable aggregates of tillage systems in all plots. The highest sum of water stable aggregates values were found for RCT (40\%-42.1\%), in in the average of 3 years. However, the lowest sum of water stable aggregates was reported for CT (22.3\%-23.5\%). These results were supported by Arshad et al. (1999), where no-tillage improved aggregate stability in surface soil compared to CT. Intensive tillage systems can cause the disruption of water stable aggregates and loss of organic content.

Table 4. Effects of tillage systems on sum of microaggregates and water stable aggregates as a percentage coefficient of soil structure

\begin{tabular}{|c|c|c|c|c|c|c|c|}
\hline \multirow[b]{2}{*}{ A } & \multirow[b]{2}{*}{ B } & \multirow[b]{2}{*}{ C } & \multicolumn{3}{|c|}{ Sum of micro-aggregates (\% ) } & \multirow{2}{*}{$\begin{array}{c}\text { Sum of water stable } \\
\text { aggregates, } \%\end{array}$} & \multirow{2}{*}{$\begin{array}{l}\text { Coefficient of soi } \\
\text { structure }\end{array}$} \\
\hline & & & $0-10 \mathrm{~cm}$ & $10-20 \mathrm{~cm}$ & $0-20 \mathrm{~cm}$ & & \\
\hline \multirow{3}{*}{ A1 } & \multirow{3}{*}{ B1 } & $\mathrm{C} 1$ & 37.0 & 35.2 & $36.1 \pm 1.25$ & $22.4 \pm 0.29$ & $0.56 \pm 0.004$ \\
\hline & & $\mathrm{C} 2$ & 32.5 & 31.9 & $32.2 \pm 1.20$ & $23.5 \pm 0.51$ & $0.58 \pm 0.003$ \\
\hline & & $\mathrm{C} 3$ & 28.1 & 30.0 & $29.0 \pm 1.11$ & $22.3 \pm 0.66$ & $0.57 \pm 0.011$ \\
\hline \multirow{6}{*}{ A2 } & \multirow{3}{*}{ B2 } & $\mathrm{C} 1$ & 45.8 & 43.2 & $44.5 \pm 2.12$ & $40.0 \pm 1.75$ & $0.91 \pm 0.012$ \\
\hline & & $\mathrm{C} 2$ & 42.5 & 44.1 & $43.3 \pm 1.51$ & $41.1 \pm 1.97$ & $0.83 \pm 0.011$ \\
\hline & & $\mathrm{C} 3$ & 43.5 & 45.5 & $44.5 \pm 1.56$ & $40.8 \pm 2.25$ & $0.87 \pm 0.010$ \\
\hline & \multirow{3}{*}{ B3 } & C1 & 47.2 & 46.8 & $47.0 \pm 1.75$ & $41.5 \pm 2.09$ & $0.90 \pm 0.013$ \\
\hline & & $\mathrm{C} 2$ & 44.2 & 46.2 & $45.2 \pm 2.14$ & $42.1 \pm 2.04$ & $0.94 \pm 0.018$ \\
\hline & & C3 & 48.3 & 46.5 & $47.4 \pm 2.28$ & $41.9 \pm 2.16$ & $0.98 \pm 0.019$ \\
\hline
\end{tabular}

A1: Conventional Tillage (CT), A2: Resource Conserving Technology (RCT)

The analysis of soil structure during rapeseed vegetation period with minimal soil treatment, shows a satisfactory structural condition of arable layer $(0-20 \mathrm{~cm})$, the share of valuable macro-aggregates was between $43.3 \pm 1.51 \%$ and $47.4 \pm 2.28 \%$, aggregates was between $40.0 \pm 1.75 \%$ and $42.1 \pm 2.04 \%$. In the 0 $10 \mathrm{~cm}$ section of arable soil layer, these indicators indicate a more visible change. After flat cutting soil to a depth of 16-18 cm, the amount of soil macro-aggregates was between $43.3 \pm 1.51$ and $44.5 \pm 1.56 \%$, and water-resistant aggregates was between $40.0 \pm 1.75$ and $41.1 \pm 1,97 \%$. Flat cutting to a depth of $12-14 \mathrm{~cm}$ had a significant impact on these indicators, where the sum of macro-aggregates rised from $45.2 \pm 2.14 \%$ to $47.4 \pm 2.28 \%$ and water stable aggregates from $41.5 \pm 2.09 \%$ to $42.1 \pm 2.04 \%$.

In the soil management, persistency and stability of soil aggregation is associated with the size of aggregates (Traore et al. 2000; Whalen and Chang, 2002). Nyamangar et al. (1999) indicated that there is need to root secretions in the soil for aggregates to be increased. Martens (2000) reported increases of water stable aggregates as a result of corn crop residues, and suggested less soil inverting methods to increase soil aggregation. Shaver et al. (2002) noted that no till cropping in wheat-corn rotation returned more crop residue, decreased bulk density, increased porosity and improved soil aggregation compared to wheatfallow. Bronik and Lal (2005) noticed the effectiveness of organic matter and decomposition degree on the stability of aggregates. On the other hand, Abiven et al. (2008) determined the correlation between decomposition characters of crop residues and soil aggregates. Meanwhile Shaver et al. (2002) determined increase of macro aggregates and total porosity due to high aggregate stability which in turn causes in high infiltration and water use efficiency. Kasper et al. (2009) determined the amounts of water stable aggregates under conventional and reduced tillage treatments as $18,2 \%$ and $18,9 \%$, respectively, whereas it was found as $37,6 \%$ at minimum tillage practice. Besides, authors noted conventional tillage interfere more natural soil properties than reduced and minimum tillage.

Soil aggregates are a reflection of soil structure and texture. The combined group of soil particles is stronger rather than a single one. Aggregate stability is prominently a multi-parameter effect on the soil properties (Kalhoro et al., 2017). Along with soil water-resistance, the effectiveness of minimal tillage was estimated by the soil structure coefficient. Under CT of rapeseed cultivation, the value of this indicator, depending on presowing tillage, ranged between $0.56 \pm 0.004$ and $0.58 \pm 0.003$, which indicated that soil structure was unsatisfactory. Under RCT, tillage minimization provided restoration of aggregate composition and soil structure, where structural coefficient increased with an average from $0.56 \pm 0.004$ to $0.98 \pm 0.019$, which indicated good soil structure (Figure 4).

These results confirm the typical beneficial effect of the lack of disruption of the soil structure (RCT). In Rapseed cultivation, this is consequence of the protection of the dense vegetation, without handling disturbances. According to Eltz et al. (1989), the larger values found for soil aggregate stability and soil structure under RCT, when compared to CT, are related to the lack of mechanical disruption of the soil and to 
the protection that plant residues offer to the surface, contributing to better aggregation. The increase of the stability of aggregates in the surface layer in RCT soil is a good effect because it reduces the susceptibility of the soil to erosion and losses caused by heavy rainfall, management, and wind (Freitas et al., 1999; Hevia et al., 2007). In this present study RCT improved soil aggregation properties after continuous CT, turning them more similar to the original state under native vegetation.

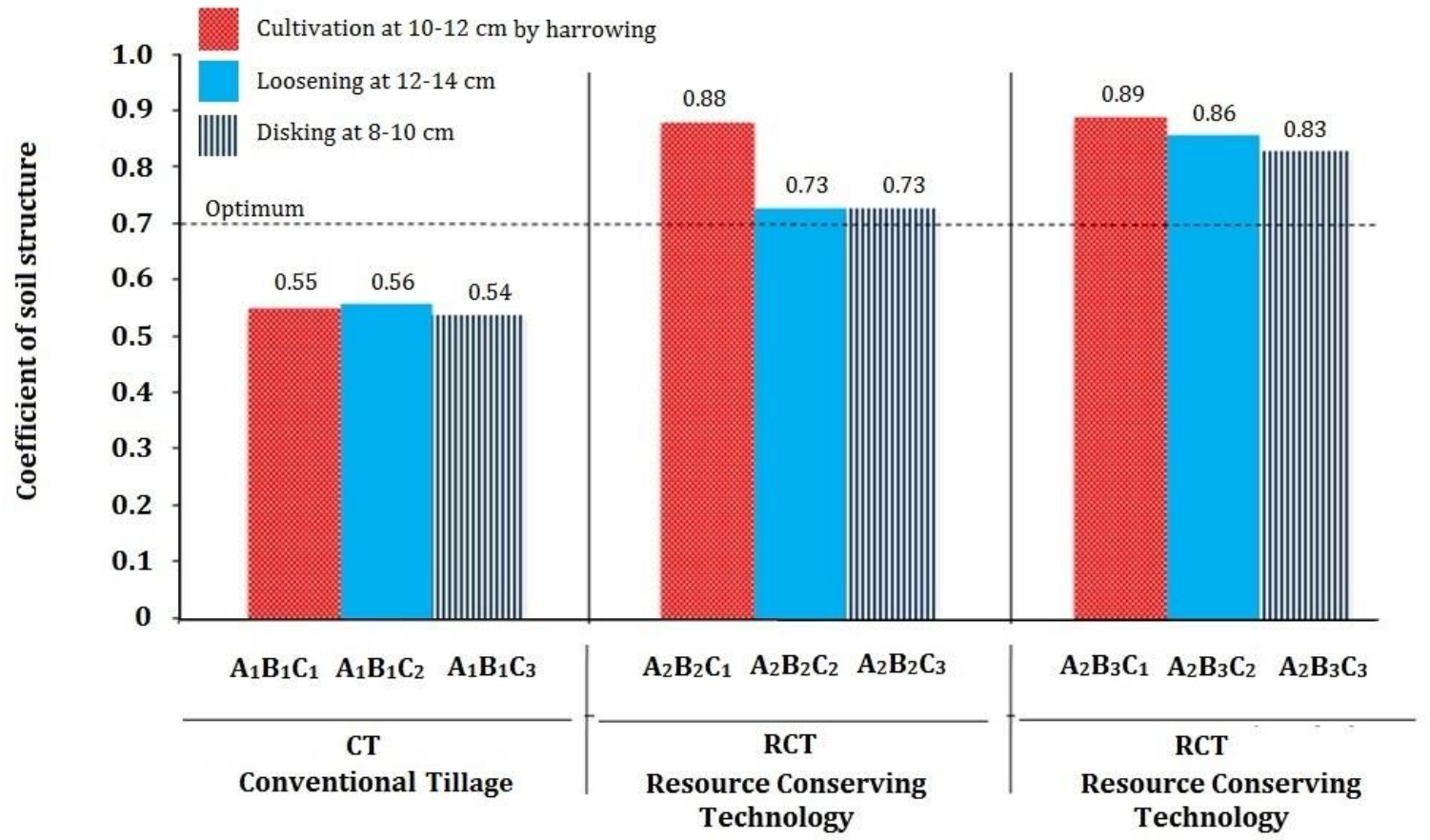

Figure 4. Effects of Conventional Tillage (CT) and Resource Conserving Technology on coefficient of soil structure

\section{Rapeseed yield and yield components}

The investigation results revealed that the rapeseed density, number of pods, number of seeds, 1000 seed weight and rapeseed yield were affected by tillage treatments as shown in Table 5. Under RCT, where flat-cut treatment (A2B2) was carried out to a depth of $16-18 \mathrm{~cm}$, the rapeseed density was $80.1 \%$, and with a processing depth of $12-14 \mathrm{~cm}$, it was $78.6 \%$. The density of growing rape plants depends on technology of cultivation and agrophysical indicators of soil fertility. Density of plants increases with improvement of aggregate composition and structure of soil. With a satisfactory soil structure after flat-cut treatment, due to improvement in moisture content of sowing rapeseed, the plant density increased, where the number of plants per $\mathrm{m}^{2}$ was between 78.6 and $80.1 \%$.

Table 5. Impact of tillage practices on mean values of rapeseed density, number of pods, number of seeds, 1000 seed weight and rapeseed yield

\begin{tabular}{lccccc}
\hline & $\begin{array}{c}\text { Rapeseed density } \\
\text { (Number } / \mathrm{m}^{2} \text { ) }\end{array}$ & $\begin{array}{c}\text { Number of pods } \\
\text { (pieces / plant) }\end{array}$ & $\begin{array}{c}\text { Number of seeds, } \\
\text { (pieces/plant) }\end{array}$ & $\begin{array}{c}1000 \text { seed weight } \\
\text { (gr) }\end{array}$ & $\begin{array}{c}\text { Rapeseed } \\
\text { Yield (t/ha) }\end{array}$ \\
\hline $\mathbf{A}_{\mathbf{1}} \mathbf{B}_{\mathbf{1}}$ (CT) & $69.7 \pm 2.6$ & $12.4 \pm 0.36$ & $297 \pm 11.5$ & $5.8 \pm 0.06$ & $1.73 \pm 0.059$ \\
$\mathbf{A}_{\mathbf{2}} \mathbf{B}_{\mathbf{2}}$ (RCT) & $80.1 \pm 2.9$ & $18.1 \pm 0.88$ & $405 \pm 19.5$ & $6.4 \pm 0.11$ & $2.11 \pm 0.082$ \\
$\mathbf{A}_{\mathbf{2}} \mathbf{B}_{\mathbf{3}}$ (RCT) & $78.6 \pm 2.1$ & $17.8 \pm 0.61$ & $389 \pm 13.7$ & $6.2 \pm 0.07$ & $1.96 \pm 0.071$ \\
\hline
\end{tabular}

One of the elements of crop structure - the number of pods on one plant, depending on primary tillage, showed that the best result was obtained on average with 17.8-18.1 pieces/plant, and the same number of seeds per plant plants 389-405. The number of seeds in one plant was $92-108$ pieces less compared to CT. The most basic indicator of crop structure is the 1000 seed weight. Under RCT of rapeseed cultivation compared to CT, the mass of 1000 seed weight averages were over the years between $5.8 \mathrm{~g}$ and $6.2-6.4 \mathrm{~g}$.

The magnitude of tillage effects varies with the use of tillage implements. CT decreases the bulk density, increases the soil porosity, infiltration rate and hydraulic conductivity (Kanwar, 1989; Meek et al., 1992; Dao, 1996; Xu and Mermoud, 2001; Shaver et al., 2002; Roscoe and Buurman, 2003; Bronik and Lal, 2005). As a result, soil becomes permeable, aerated and having good physical condition for rapseed growing. On the other hand, RCT increases the bulk density, soil resistance and mechanical impedance of soil for which poor physical condition may be developed. In our experiment, soil perhaps were more loose compared to other tillage treatments, which might have permited the roots to enter into the deeper layer for uptaking water and mineral nutrients. Positive physiological and metabolic activities of rapseed were indicated by higher 
density, number of pods, number of seeds, 1000 seed weight. Hence, highest yield of rapseed was obtained using RCT because of higher density, number of pods, number of seeds, 1000 seed weight. The pattern of changes in the addition of the arable layer of soil as a result of the application of the technique of RCTMinimum (Mini-till) tillage revealed indicated an increase in the quality indicators of the soil resource and the restoration of the agro-physical factors of soil fertility.

The yield of rapeseed with the cultivation of RCT in 2016, 2017, 2018 and 3-year average yield are given in Table 6. The yield of rapeseed in the years of research with the CT was $1.73 \mathrm{t} / \mathrm{ha}$, and with the RCT, it increased to $1.96-2.11 \mathrm{t}$ / ha.

Table 6. Impact of tillage practices on rapeseed yield

\begin{tabular}{|c|c|c|c|c|c|c|}
\hline \multirow{2}{*}{$\begin{array}{l}\text { Soil Tillage } \\
\text { Methodology }\end{array}$} & \multicolumn{3}{|c|}{ Research Years } & \multirow{2}{*}{$\begin{array}{l}\text { Average yield } \\
\text { (t/ha) }\end{array}$} & \multicolumn{2}{|c|}{ Yield gain } \\
\hline & 2016 & 2017 & 2018 & & (t/ha) & $\%$ \\
\hline$A_{1} B_{1}$ & 1,76 & 1,69 & 1,75 & 1,73 & St & - \\
\hline$A_{2} B_{2}$ & 2,16 & 2,04 & 2,14 & 2,11 & 0,38 & 22,0 \\
\hline$A_{2} B_{3}$ & 1,98 & 1,93 & 1,99 & 1,96 & 0,23 & 13,3 \\
\hline $\mathrm{Sd}_{05}, \mathrm{t} / \mathrm{ha}$ & 1,21 & 0,12 & 0,16 & 0,11 & & \\
\hline$S_{x}, \%$ & 2,43 & 2,43 & 2,87 & 3,04 & & \\
\hline
\end{tabular}

Yield results were processed by analysis of variance, where the lowest value of the standard deviation $\left(\mathrm{Sd}_{05}\right)$ between the control and the studied variants was $0.12 \mathrm{t} / \mathrm{ha}$ and the accuracy of the experiment was $\mathrm{Sx}, \%=$ $2.43 \%$. According to the results of ANOVA, it is considered significant when the obtained difference of the studied variants exceeds the $\mathrm{Sd}_{05}$. For example, in 2016, the yield difference between RCT and CT was within 0.22-0.40 t/ha. If we compare, the yield difference of the cultivation with RCT $(0.40 \mathrm{t} / \mathrm{ha})$ where $\mathrm{Sd}_{05}=0.12$, it was proved that the RCT provided a reliable significant yield increase up to $22.7 \%$. In all the years of studying both methods of RCT, a significant yield increase was achieved, within $0.23-0.38 \mathrm{t} / \mathrm{ha}$. Thus, the RCT of rapeseed provided the greatest efficiency, where the yield of rapeseed increased by $13.3 \%$ and $22.0 \%$.

\section{Economic Evaluation}

In the series, under the conditions of the foothill zone of south-east of Kazakhstan, we gave the economic efficiency of RCT techniques. Economic efficiency was calculated to assess the effectiveness of economic and natural resources in the agro-ecosystem, as well as to assess specific areas of increasing economic efficiency in the cultivation of crops, ensuring the preservation and reproduction of the natural environment and increasing yields. The economic efficiency of rapeseed cultivation technology was carried out on the basis of rapeseed cultivation technology maps, taking into account the direct costs of CT and RCT according to the standards, rates and prices existing at the farm.

The following indicators were used in the comparative assessment of the efficiency of the methods of using the RCT of rapeseed cultivation:

- Rapeseed crop yield when studying the effect of minimization (Mini-Till) of tillage,

- Production costs per 1 hectare of rapeseed (based on rapeseed cultivation maps) from 1 ha (yield multiplied by the cost of 1 ton of rapeseed),

- Net income (sales revenue minus costs of rapeseed cultivation),

- Production profitability in rapeseed cultivation (net income divided by the cost and multiplied by 100\%) depending on the studied techniques of the technology.

Crop yield was the main indicator for assessing the economic efficiency of rapeseed, while evaluating the ratio of yield and production costs. Increasing the yield of a cultivated rapeseed crop implies its economic efficiency (Table 7).

Table 7. Economic efficiency of rapeseed under Conventional Tillage (CT) and Resource Conserving Technology (RCT) in foothill zone conditions of South-Eastern Kazakhstan

\begin{tabular}{lcc}
\hline Economic efficiency indicators & CT & RCT \\
\hline Average yield, t/ha & 1,73 & 2,10 \\
Cost of 1 tonna of production, \$ & 165,7 & 165,7 \\
Sales revenue, \$/ha & 286,6 & 347,9 \\
Cultivating expenses, \$/ha & 219,1 & 171,7 \\
Relative net profit, \$/ha & 67,5 & 176,2 \\
Rentability of soy cultivation, \% & 30,8 & 102,6 \\
\hline Net profit from application of resource- saving technology, \$/ha & 38,0 \$/ha \\
\hline
\end{tabular}


Evaluation of the economic efficiency of RCT in the foothill zone of the south-east of Kazakhstan shows that with CT of rapeseed, the yield was 1.73 tones/ha, where the direct costs of its cultivation was $219.1 \$ /$ ha. With the sale of the harvest, revenue amounted to $286.6 \$ /$ ha, conditionally net income $-67.5 \$ /$ ha, which ensured the profitability of rapeseed cultivation only $30.8 \%$.

Evaluation of the economic efficiency of RCT in the foothill zone of the south-east of Kazakhstan shows that with CT of rapeseed, the yield was 1.73 tones/ha , where the direct costs of its cultivation was $219.1 \$ / \mathrm{ha}$. With the sale of the harvest, revenue amounted to $286.6 \$ /$ ha, conditionally net income $-67.5 \$ / \mathrm{ha}$, which ensured the profitability of rapeseed cultivation only $30.8 \%$.

With the use of elements of RCT, the amount of costs was reduced due to the minimum cost of fuel and lubricants and additional funds with minimal tillage of RCT equal to $47.4 \$$ /ha and the cost of applying an environmentally safe dose of herbicide in the fight against debris and other types works on the cultivation of rapeseed from 219.1 to $171.7 \$ /$ ha, where the cost of production decreased.

Comparative evaluation of economic indicators from the use of techniques of RCT shows that minimizing tillage contributed to an increase in income from 67.5 \$/ha (CT) to 176.2 \$/ha (RCT). On the basis of economic efficiency, the purity of the use of RCT of rapeseed cultivation, where the conditional net income from the use of RCT techniques (where the tillage technology pass is reduced by 2 times) rises to 176.2, $\$ /$ ha, which increases the profitability of cultivation from $30,8 \%$ to $102.6 \%$.

\section{Conclusion}

Thus, for the first time, the possibility of efficient use of resources and energy saving in an agroecosystem has been established. The restored parameters of the agrophysical indicators of soil fertility are determined. The decrease in total energy costs by $47.4 \$ /$ ha , which is $21.6 \%$ due to the cost of fuel and additional funds with minimal tillage of RCT. In comparison with the waste treatment, while minimizing the cost processing is reduced. It has been established that with CT, the cost is 219.1 \$ ha, and with RCT, only 171.7 \$ $/$ ha. Where conditional net income is 67.5 to $176.2 \$$ / ha, additional income from each hectare of 38.0 thousand tenge is received. Indicators of the economic efficiency of the methods of RCT of rapeseed proves that the replacement of the main dump processing with small-plow cutting (Mini-till) is abundant, ensuring the effective use of soil resources and the conservation and restoration of the soil fertility agro-physical factors and the rapeseed agroecosystem energy saving in the foothill zone of South-East Kazakhstan.

\section{References}

Abiven, S., Menasseri, S., Angers, D.A., Leterme, P., 2008. A model to predict soil aggregate stability dynamics following organic residue incorporation under field conditions. Soil Science Society of America Journal 72(1); 119-125.

Acar, M., Celik, I., Günal, H., 2018. Effects of long-term tillage systems on aggregate-associated organic carbon in the eastern Mediterranean region of Turkey. Eurasian Journal of Soil Science 7(1): 51-58.

Arshad, M.A., Franzluebber, A.J., Azooz, R.H., 1999, Components of surface soil structure under conventional and notillage in Northwestern Canada. Soil and Tillage Research 53(1): 41-47.

Bessam, F., Mrabet, R., 2003. Long-term changes in soil organic matter under conventional and no-tillage systems in semiarid Morocco. Soil Use and Management 19(2):139-143.

Bronik, C.J., Lal, R., 2005. Manuring and rotation effects on soil organic carbon concentration for different aggregate size fractions on two soil in northeastern Ohio, USA. Soil and Tillage Research 81(2); 239-252.

Carpenter, S.R., DeFries, R., Dietz, T., Mooney, H.A., Polasky, S., Reid, W.V., Scholes, R.J., 2006. Millennium Ecosystem Assessment: Research Needs. Science 314(5797): 257-258.

Chauhan, B.S., Singh, R.G., Mahajan, G., 2012. Ecology and management of weeds under conservation agriculture: a review. Crop Protection 38:57-65.

Dao, T.H., 1996. Tillage system and crop residue effects on surface compaction of a Paleustoll. Agronomy Journal 88(2): 141-148.

Duru, M., Therond, O., Martin, G., Martin-Clouaire, R., Magne, M.A., Justes, E., Journet, E.P., Aubertot, J.N., Savary, S., Bergez, J.E., Sarthou, J.P., 2015. How to implement biodiversity-based agriculture to enhance ecosystem services: a review. Agronomy for Sustainable Development 35(4): 1259-1281.

Eltz, F.L.F., Peixoto, R.T.G., Jaster, F., 1989. Efeito de sistemas de preparo do solo nas propriedades fi'sicas e quı́micas de um Latossolo Bruno A’ lico. Revista Brasileira de Cienncia do Solo 13: 259-267.

FAO, 2013. Conservation Agriculture in Central Asia: Status, Policy, Institutional Support and Strategic Framework for its Promotion. FAO Sub-Regional Office for Central Asia (FAO-SEC) Ankara, Turkey. 60p. Available at [Access date: 18.04.2018]: http://www.fao.org/docrep/019/i3275e/i3275e.pdf

Franzluebbers, A.J., 2002. Soil organic matter stratification ratio as an indicator of soil quality. Soil and Tillage Research 66(2): 95-106. 
Freitas, P.L., Zobel, R.W., Snyder, V.A., 1999. Corn root growth in soil columns with artificially constructed aggregates. Crop Science 39 (3): 725-730.

Gomiero, T., 2016. Soil Degradation, Land Scarcity and Food Security: Reviewing a Complex Challenge. Sustainability 8, 281.

Hevia, G.G., Mendez, M., Buschiazzo, D.E., 2007. Tillage affects soil aggregation parameters linked with wind erosion. Geoderma 140(1-2): 90-96.

Hobbs, P.R., Sayre, K., Gupta, R., 2008. The role of conservation agriculture in sustainable agriculture. Philosophical Transactions of the Royal Society of London. Series B, Biological Sciences 363(1491): 543-555.

Jones, B.J.Jr., 2001. Laboratory guide for conducting soil tests and plant analysis. CRC Press. New York, USA.

Kachinsky, N.A., 1958. Mechanical and microagregate composition of soils; methods for study. USSR Academy of Science Publishers, Moscow, Russia. 177p. [in Russian].

Kalhoro, S.A., Xu, X,. Chen, W., Hua, R., Raza, S., Ding., 2017. Effects of different land-use systems on soil aggregates: A case study of the Loess Plateau (Northern China). Sustainability 9, 1349.

Kanwar, R.S., 1989. Effect of tillage system on the variability of soil water tensions and water content. Transactions of the ASAE 32(2): 605-610.

Kasper, M., Buchan G.D., Mentler, A., Blum, W.E.H., 2009. Influence of soil tillage systems on aggregate stability and the distribution of C and N in different aggregate fraction. Soil and Tillage Research 105(2): 192-199.

Kassam, A., Friedrich, T., Shaxson, F., Pretty, J., 2009. The spread of conservation agriculture: justification, sustainability and uptake. International Journal of Agricultural Sustainability 7(4): 292-320.

Martens, D.A., 2000. Management and crop residue influence soil aggregate stability. Journal of Environmental Quality 29(3): 723-727.

Meek, B.D., Rechel, E.A., Cater, L.M., DeTar, W.R., Urie, A.L., 1992. Infiltration rate of a sandy loam soil: Effets of traffic, tillage, and plant roots. Soil Science Society of America Journal 56(3): 908-913.

Mrabet, R., Ibno-Namr, K., Bessam, F., Saber, N., 2001. Soil chemical quality changes and implications for fertilizer management after 11 years of no-tillage wheat production systems in semiarid Morocco. Land Degradation and Development 12(6): 505-517.

Nyamangara, J., Piha, M.I., Kirchmann, H., 1999. Interactions of aerobically decomposed cattle manure and nitrogen fertilizer applied to soil. Nutrient Cycling in Agroecosystems 54(2); 183-188.

Palm, C., Blanco-Canqui, H., DeClerck, F., Gatere, L., Grace, P., 2013. Conservation agriculture and ecosystems services: an overview. Agriculture, Ecosystems \& Environment 187: 87-105.

Roscoe, R., Buurman, P., 2003. Tillage effects on soil organic matter in density fractions of a Cerrado Oxisol. Soil and Tillage Research 70(2): 107-119.

Rowell, D., 1994. Soil Science: Methods and Applications. Longman Group UK Limited, UK. 350p.

Ruiz-Colmenero, M., Bienes, R., Eldridge, D.J., Marques, M.J., 2013. Vegetation cover reduces erosion and enhances soil organic carbon in a vineyard in the central Spain. Catena 104:153-160.

Saparov, A., 2014. Soil Resources of the Republic of Kazakhstan: Current Status, Problems and Solutions. In: Novel Measurement and Assessment Tools for Monitoring and Management of Land and Water Resources in Agricultural Landscapes of Central Asia. L. Mueller, A. Saparov, Lischeid, G., (Eds.). Environmental Science and Engineering. Springer International Publishing. Switzerland. pp.61-73.

Sapkoda, T.B., Jat, M.L., Jat, R.K., Kapoor, P., Stirling, C., 2016. Yield estimation of food and non-food crops in smallholder production systems. In: Rosenstock, T.S., Rufino, M.C., Butterbach-Bahl, K., Wollenberg, L., Richards, M., (Eds.) Methods for measuring greenhouse gas balances and evaluating mitigation options in smallholder agriculture. Springer. pp.163-174.

Savinov N.O., 1936. Soil Physics. Sielchozgiz Press, Moscow, Russia. [in Russian].

Shaver, T., Peterson, G., Ahuja, L., Westfall, D., Sherrod, L., Dunn, G., 2002. Surface soil properties after twelve years of dryland no-till management. Soil Science Society of America Journal 66(4): 1296-1303.

Silva, I.F., Mielniczuk, J., 1998. Aggregate stability as affected by cropping systems and soil characteristics. Revista Brasileira de Ciência do Solo 22(2): 311-317.

Telles, T.S., Guimarães M.F., Dechen, S.C.F., 2011. The costs of soil erosion. Revista Brasileira de Ciência do Solo 35(2): 287-298.

Tisdall, J.M.. Oades, J.M., 1982. Organic carbon and water stable aggregates in soils. European Journal of Soil Science 33(2): 141-163.

Townsend, T.J., Ramsden, S.J., Wilson, P., 2016. Analysing reduced tillage practices within a bio-economic modelling framework. Agricultural Systems 146: 91-102.

Traoré, O., Groleau-Renaud, V., Plantureux, S., Tubeleh, A., Boeuf-Tremblay, V., 2000. Effect of root mucilage and modelled root exudates on soil structure. European Journal of Soil Science 51(4); 575-581.

Whalen, J.K., Chang, C., 2002. Macroaggregate characteristics in cultivated soils after 25 annual manure applications. Soil Science Society of America Journal 66(5): 1637-1647.

$\mathrm{Xu}, \mathrm{D} ., \mathrm{Mermoud}, \mathrm{A} ., 2001$. Topsoil properties as affected by tillage practices in North China. Soil and Tillage Research 60(1-2): 11-19. 